KAMIL STACHOWSKI

Jagiellonian University in Kraków

kamil.stachowski@gmail.com

OLAF STACHOWSKI

Jagiellonian University in Kraków

olstach@gmail.com

\title{
POSSIBLY ORIENTAL ELEMENTS IN SLAVONIC FOLKLORE. MAMUNA [PART 2]
}

Keywords: Slavonic, Oriental, etymology, mythology, folklore

\begin{abstract}
A specialist in Middle Eastern languages will likely be quick to associate Pol. mamuna 'an ape-like mythological creature' with Ar./Pers./Tkc. majmun 'ape'. It is possible and indeed probable that this name is an Oriental borrowing applied to an ancient native belief, but a closer inspection reveals at least several other possibilities tangled in an ethnolinguistic web of potential conflations and contaminations. This paper presents the ethnographic background and some etymological ideas, though without as yet a definite answer.
\end{abstract}

\section{Etymology}

The belief in mamunas, and together with it the word itself, is most widely spread in Poland among the Slavonic countries. To the best of our knowledge, also all the existing etymological proposals focus only on Polish. Except for one, all reach out and search for the source among not necessarily very similar creatures outside Poland and Polish folklore, but at the same time overlook obviously related beliefs in the neighbouring cultures. We are not yet certain that the new bits of evidence presented in this paper bring us any closer to uncovering the origin of mamunas, but they have undoubtedly proved helpful in rebutting some of the previous ideas. 


\subsection{Carpathian mamuna}

Let us briefly inspect all those languages and countries which we suspect might be of any relevance for us here. When doing this, we will generally omit the Biblical Mammon 'wealth', 'personification of greed'; it is rather widespread but, as will be shown in 3.2.2, quite unlikely to have a deeper connection to our creature than maybe an occasional, local, secondary contamination. The countries and nations are in the clockwise geographical order with Poland as the centre.

For Lithuania, which would have been anyway slightly too distant geographically, we have not been able to find reports of sufficiently similar creatures or similar names. Perhaps the closest is maũmas baũbas, a demon used to scare children (Balsys 2014: 73, 85; LKŽ). We suppose that it may be connected in some way to Eastern Slav. русалки and/or G Kornmuhme (see 2 and 3.2.3), perhaps even eventually stem from the same ethnographic complex, but it seems unlikely that it should be the direct source of our mamuna.

For Polish-Lithuanian Tatars, we have not been able to find even this much. They, too, would have been somewhat too distant geographically (Kryczyński 1938: after 52, unnumbered map; Tyszkiewicz 1989: 236), but unlike Lithuanians they could be hoped to have brought to Europe and preserved the belief in bičin, an ape-like feminine demon known to abduct and kill lone travellers, especially children (more on this in 3.2.7). Unluckily, this seems to not be the case (Musa Czachorowski - p.c.; see also Kryczyński 1938; Borawski, Dubiński 1986; Tyszkiewicz 1989).

For Belarus, specifically for the Polesia region, Vinogradova and Levkievskaja (2012: 470, 775) report the figure of a terrible hag, hirsute, with a huge bust, and generally looking like an ape. Surely, it is not unconnected to eastern Pol. matpa 'mamuna' mentioned by Budziszewska (1985: 119). A similar image, Vinogradova and Levkievskaja continue, appears under the name of pycaлкa in stories meant to scare children away from going into the fields. It shares this and some other characteristics with G Kornmuhme (see 3.2.3), but seems to not go by any name that could be considered reminiscent of mamuna. We were also unable to find any such word in Sanbko et al. (2004); Paškoŭ et al. (2005-2006) or any other source.

For Russia, we could find no accounts of our creature. In fact, several works cite the word mamuna, but always adding that it is not an eastern Slavonic beast; see e.g. Anisov (1994 s. vv. боги́нки and подме́ныи), Zelenin (1995: 21, 226, 312, 426), Gura (1997: 241), Levkievskaja (2000: 505), Tolstoj (2003: 563), Vinogradova (2004: 176). All five describe it as specifically Polish; Anisov (s.v. боги́нки) also mentions the Carpathian area. Other sources either do not include our word at all, or only cite the Biblical Mammon (see 3.2.2) or ORuss. мамонъ (3.2.4) (e.g. Fasmer 1967; Vinogradova 2000; Belova 2001; Černyh 2001; see also Preobraženskij 1910, s.v. мамо́на where unusual meanings are attested: 'belly, intestines', 'glutton', 'layabout').

For the Ukraine, the only relevant attestations we were able to find are the following three words included by Hrinčenko in his 1907-1909 dictionary (after UkrLit): 
маму́н 'an evil spirit that abducts women and confuses people' (after Šuchevyč 1899: 43 [perhaps a misprint for 69]; see also Hnatjuk 1912: XXVI; Janów 2001 s.v. maт'un) | маму́на 'a closed, veiled figure' (after Verchatskyj 1902: 433f), according to Budziszewska (1985: 119) also 'mask', 'masked figure', and 'witch'| маму́нка 'doll, puppet' (after Verchatskyj 1902: 434). It appears that the geographical reach is limited to the south-western tip of the country, the lands of Hutsuls and Lemkos, close to the Polish and Slovak border. For the semantics, cf. Pol. 'dolls made from colourful pieces of cloth, hung on the door or in a window to scare away forces that could harm the baby' in the Rzeszów area (Budziszewska 1985: 118).

For Romania, we found an attestation of mamona 'a demonic figure who changes children', but it is in a Polish dialect in Bukovina (Greń, Krasowska 2008). In actual Romanian, the closest shape is mamón, but its meaning 'devil', and particularly 'the devil of greed', reveals that it is a borrowing from the Bible (see 3.2.2; dexonline s.v. mamon; DEX; Hulubaș 2009: 608). The second closest modern shape is maimúță, archaically maimun, but the meaning is simply 'monkey, ape', and dialectally 'scarecrow' - clearly an independent borrowing from Tksh. majmun 'monkey, ape' (Leschber 2011: 49).

For Bulgaria, there is the Tksh. майму̀на 'monkey, ape' (BER; Gerovъ 1899; ĖSSJa), but apparently not anything closer to our mamuna (see e.g. Gerovъ 1899; Georgieva 1993; Plotnikova 2004, 2009) - except perhaps мàмники 'wizards', ма̀мниия 'a species of butterfly', but dialectally also 'witch, sorceress', and житомамниu, $a$ 'a witch who uses magic to take away fertility' or 'a witch who uses magic to move prosperity from one place to another' (BER s.v. $\mathcal{M a ̀ M} я$; ĖSSJa s.v. *mambnica). Both these sources are most probably right to derive those words from ${ }^{*}$ mamiti 'to delude, to beguile, to deceive', meaning that their connection to mamuna is entirely superficial.

For Slovakia, we have attestations of mamuna mamona with meanings related to those of Pol. mamuna: 'night terrrors', 'superstition', 'scare', 'magic' (Smatana 2004: 160), 'a repentant soul wandering the world in the form of a white dog, white horse, a dead person, or shapeless white mass, often not seen but only felt, who leads people in forests until exhaustion, leaving them in terrible fear afterwards' (Valencova 2013: 198). The word is used in north-eastern Slovakia, in the Prešov area (not very far from the lands of Hutsuls and Lemkos). Semantically, this is not a perfect match, but definitely closer than the Bulgarian ones. We have not been able to find any more similar words, apart from the Biblical mamon(a) (HSSJ; SSJ).

For Czechia, again apart from the Biblical mamon $\sim$ mamona $\sim$ mammon (Jungmann 1836; Gebauer 1970; PSJČ), we have mamon mamona in the meanings 'any supernatural appearance', 'bogeyman', and 'an evil, dangerous man' (Bartoš 1885: 38, 4of; Kott 1890 s.vv. mamon, and mamona; and Zíbrt 1888, who derives it from the Biblical word). Geographically, it appears to be limited to western and southern Moravia. Semantically, these are perhaps even closer to Pol. mamuna than the Slovak attestations.

For Germany, we could find no more than Kornmuhme for the ethnographic side (see 3.2.3), and little more than the Biblical Mammon for the linguistic side (see e.g. 
EM; Wörterbuchnetz ${ }^{11}$ ). Both show a certain degree of similarity to our beast and its name but neither is likely to actually have been its source (see 3.2.2 and 3.2.3). The last possible creature is Bäumann $\sim$ Bomann $\sim$ Bumann..$^{2}$ It is a fairly prospective candidate from the phonetic point of view, but sadly appears to be too distant ethnographically to be regarded as a possible source (HdA s.v. Bumann).

It seems, then, that mamuna inhabits central-southern Poland (see Fig. 1) and northern Carpathians: Cz. mamon, mamona | Pol., Slk. mamuna, mamona| Ukr. маму́н, маму́на, мами́нка. It is not very clear what the original meaning of our word was; the most specific definitions come from Poland and Slovakia (see above and 3.2) but they are hardly compatible. The one component that is common to almost all is 'evil spirit', usually one dangerous to children because it abducts them, or is merely used as a scare. The eastern meanings 'doll ...', 'mask', and 'masked figure' seem to be secondary (see 2 above). We should also take into account the gradual erosion of folk beliefs. What were originally various creatures become sometimes conflated, their names confused, and their defining properties distorted or forgotten. Perhaps the Czech and Slovak mamuna only seem so different from their Polish and Ukrainian namesakes because they took over the characteristics of some other beast?

Transmission over the Carpathians is perfectly possible (see above Pol.dial. mamona in Romania, and Stachowski 2005, 2007, 2012, and others). It is perhaps less likely that a word from the dialect of Polish Gorals (highlanders) would spread nearly as far northwards as Warsaw; the opposite direction seems to be more probable. However, central Poland is not a region that is particularly prone to borrowing (see 3.2), and mamuna is not only widely spread there, it is also almost limited to this area. The situation appears to have become a bit of a stalemate; we may be forced to accept that the history of mamuna does actually contain a less than probable leap.

\subsection{Polish mamuna}

Having established its background, let us now focus on Pol. mamuna because this is the word that appears to be the most attested and researched of all. The main shapes are mamuna and mamona; the pronunciations mamana and mam ${ }^{u}$ ona are probably just phonetic quirks, while mamonia and mania are local innovations in the area of Rzeszów, both irrelevant for us here. Northern Polish forms mamon, mamón, and måmůn (not indicated in Fig. 1) are probably a separate word; see 3.2.2. The common, primary meaning in Polish is 'evil spirit'. Beyond that, definitions vary in specificity, the most often recurring motifs being abducting and swapping children, anthropomorphism, femininity, ugliness, hirsuteness, harming

1 The only out of the ordinary variant is Mammona 'papaya (Carica papaya)' in Meyers Großes Konversationslexikon (www.woerterbuchnetz.de/Meyers?lemma=mammona). However it came about, we suspect it is not in any way related or indeed relevant for our mamuna.

2 We would like to express our gratitude to Dr Corinna Leschber (Institute for Linguistic and Cross-Cultural Studies, Berlin) for this piece of information, and for the discussion. 
women in childbed, boginki (see 2 above), in the south also deception, and in the east strangling of people bathing or sailing the Vistula river. Exceptionally, the meaning may have somewhat shifted away from the supernatural (e.g. 'an unlikeable, unpleasant, intrusive woman suspected of witchcraft' near Gorlice), or from the spirit itself ('dolls made from colourful pieces of cloth, hung on the door or in a window to scare away forces that could harm the baby' in the Rzeszów area). (Budziszewska 1985: 118f; Dźwigoł 2004: 111f, 164f, 180, and others; Karłowicz 1903; Pełka 1987: 92f, 146f, and others; SGP).

The geographic reach in Polish dialects is shown in Fig. 1. It is specific and important, being almost sufficient in itself to rebut some of the previously proposed etymologies. Over the period of more than a thousand years, the borders of Poland changed both very frequently and very significantly. No single region remained fully under Polish control throughout this whole time; the lands that came closest to it are those that lie in the triangle between Kraków, Sandomierz, and Warsaw. At times, they belonged to two or three relatively independent provinces during the period of fragmentation between the $12^{\text {th }}$ and $14^{\text {th }}$ centuries; they were divided between Austria and Prussia during the Third Partition in 1795, until reunification as part of the Duchy of Warsaw in 1809, they were occupied during World War I and II, but overall those are the lands that form the very core of Polish geography. As such, they are the least susceptible to foreign influence and set the bar higher for etymologies that rely on borrowing than e.g. Masuria and Warmia or Silesia would, being borderland regions and having changed hands as many times as they did.

The reach of mamuna is nearly the same as the extent of those lands, yet almost all of the several etymologies that have been offered for it agree that it was borrowed; and that there occurred a secondary contamination with the verb mamić 'to delude, to beguile'. Let us discuss the various proposed etymons.

\subsubsection{Slav. mami-}

The simplest version is that proposed by Miklosich (1886 s.v. mami-). He does not explain any details, merely mentions Slk. mamona 'supernatural appearance' while discussing mamić, and asks the reader to compare [Pol.] mamona'dziwožona [sic] who changes children'.

This suggestion is so vague that not much can be said about it. A contamination with mamić 'to delude, to beguile, to lure' is possible, indeed very likely in southern Poland (see e.g. mamuny 'evil spirits; apparitions, illusions, delusions' in Zakopane; Budziszewska 1985: 118), but the meaning of mamić does not quite suffice in itself to explain the whole of mamuna. It is mamuna's contemporary image that may contain elements of what were originally separate creatures but clearly, its primary raison d'être is to abduct and swap children; see 2 above. Our word does not have so obvious a morphological structure as to justify an etymology with such a gap in semantics.

\subsubsection{Biblical Mammon}

According to Sumców (1891: 581), an author we were not able to establish suggested in the Wista journal between 1887 and 1891 that our word stems from Biblical Mammon 
'riches' and 'personification of greed' (Pol. Mamona), later contaminated with mamić. Also Brückner (1902: 94f; 1989 [1927]), Bańkowski (200o), and Bracha (2007: 312) subscribe to this idea.

The ultimate source of Biblical Mammon is not absolutely clear; it involves Lat. mamona, Gr. $\mu \alpha \mu \omega v \tilde{\alpha} \varsigma$, Aram. māmōnā and perhaps other Semitic forms, all with the meanings 'riches, wealth', 'profit', and similar (OED). Importantly for us here, the word spread across Europe from the Bible, and owing probably to such appearances as in Mt 6:24 (Stuttgart Vulgate): "non potestis Deo servire et mamonae", it was very early cast in the role of personification of greed, became associated with the devil, and portrayed accordingly. This gives it two significant points of contact with our mamuna: the essence of its nature (evil spirit), and the physical appearance (anthropomorphic, hirsute, ugly).

We judge this to be sufficient similarity for a later contamination but it seems unlikely to us that Lat. mamona could be the actual source of Pol. mamuna. Firstly, it would be difficult to explain the semantic development. Mammon's greed is for the earthly riches; mamuna's is for children, but only so that she can place her own in their stead. Secondly, we can see little reason for the $o>u$ change in the second syllable. In the early Polish translations of the Bible, the word is either substituted with 'devil', 'riches' or similar (e.g. RP: 280; Lk 16:9 in: BLeo), or rendered consistently with o as Mammon[a], mámmon[a], or mámon (e.g. Mt 6:24 and Lk 16:9 in: BBrz, BLeo, BNie, BWuj). Thirdly, assuming the Bible as the source of Pol. mamuna would rather complicate its relation with $\mathrm{Cz}$. mamon(a), Slk. mamuna mamona, and Ukr. маму́н(a) маму́нка (see 3.1). Quite understandably, Bible translators often viewed Mammon as a personal name, left it in its original form, and thus introduced to their native language. But our mamuna is only known in central-southern Poland, and marginally in Czech, Slovak, and the southwestern tip of the Ukraine, in fairly diverse meanings, none of which is particularly similar to the Biblical Mammon, and all of which appear to be remnants of a much older stratum of beliefs (see 2 above). It is rather unlikely that all should be independent contaminations, but it is not much more probable that they should all stem from a single one - or in fact, any intermediate position between these two extremes.

On the other hand, forms that do probably stem from Lat. mamona, via G Mammon, are Cashubian and northern Polish shapes mamon, mamón, and måmi̊n 'evil spirit', 'satan', 'evil spirit guarding a buried treasure', perhaps also 'juggler,

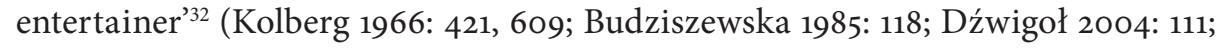

This last meaning is surprising. One way it could have come about is through a series of contaminations: Mammon \'devil' \'monkey' ’ 'juggler, entertainer'. (cf. 1. Mt 6:24; 2 . HdA s.v. Affe; Janson 1952: 13-27, and others; 3. Janson 1952: 61, 171, 192f, and others.) Each of these steps is likely in itself, but how probable is it that all of them happened together and culminated in Warmia and Masuria? Another way would be a contamination with the verb mamić 'to delude, to beguile, to lure' - very often precisely the trade of jugglers, players, and other street entertainers. We are not certain how likely this possibility is; the two words appear to fit semantically, but in our experience mamić is rarely used in connection with entertainment, though cf. Kolberg (1962: 45f). Perhaps other explanations are also possible. 
SGOWM). They seem to have no connection with children (and to have a connection with riches), their phonetics matches the German rendering (Mammon already in M. Luther's translation), they are geographically detached from the forms in $-a$, and moreover, they are used in lands which had for many centuries remained under strong German influence.

\subsubsection{G Kornmuhme}

Sumców's (1891: 582) own solution is that our word is a borrowing of G Muhme 'aunt', as used in Kornmuhme 'a corn demon', later contaminated with mamić.

Ethnographically, it is fairly easy to see why Sumców viewed G Kornmuhme as a suitable source for Pol. mamuna but the idea is actually quite problematic, and not only from the point of view of phonetics and geography but also semantically.

In German folklore, Kornmuhme is one of the many names for one of the many spirits that dwell in grain fields and crops in general. Their appearance and behaviour vary considerably, but what would be important for us here is that in the Prussian provinces of Posen and East and West Prussia they tended to take on the form of a woman (not at all necessarily old, hairy or ugly, however), and that this feminine spirit could be used as a scare for children to keep them from running off into the fields, as it was believed to abduct and do horrible things to them such as blowing their eyes out, selling them away, eating them, etc. (typically not, however, substituting their own offspring in their place). This may be a sufficient similarity for an occasional contamination but it does not quite validate G Kornmuhme as the source of Pol. mamuna. In addition, Gersten-, Korn-, Roggen-, and Weizenmuhme, -mutter and -weib (also known under other names) have some of their own unique characteristics - perhaps most notably connected with iron, such as iron breasts or a glowing, pointed piece of iron - which mamunas have not (Mannhardt 1868: 19f; Beitl 2007 [1933]: 15f, 21f, 48f; HdA s.v. Korndämonen). Cf., however, pycaлкa of the Polesia region in Belarus in 3.1.

Geography does not favour a German origin of our word, either; see 3.1. Phonetically, a transition from Muhme to mamuna is not entirely inconceivable but also not likely. It could perhaps be assumed if the idea had a strong ethnographic and historical backing which it does not.

\subsubsection{ORuss. мамонб}

Budziszewska (1985: 119f) presents two possibilities. According to one, our word was borrowed from ORuss. mamona 'simian' < Tkc. < Ar. maimun lit. 'auspicious', used as a euphemism for 'devil' because Arabs considered monkeys to be devils $>$ It. mammone 'guenon', etc., and later contaminated with mamić.

ORuss. мамонъ момонъ мамонь 'a kind of monkey', attested since 1472, stems eventually from Ar./Pers. maimūn 'monkey' (Sreznevskij 1902 s.v. мамона; Fasmer 1967; Filin 1975-). Most probably, the word entered Russian through Turkic mediation; Ottoman and most other Turkic languages are possible (majmun) but the usually more readily suspected Tatar may need to be excluded as it appears to only have the shape majmyl since at least the $19^{\text {th }}$ century; see, however, $12^{\text {th }}-14^{\text {th }} \mathrm{C}$. 
Kipch. majmun in Codex Cumanicus (Men 1680; Budagovъ 1869; Kuun 1880: 128, 304; R: 1992; Drimba 2000: 107; TatRS). More on this possibility in 3.2.7.

Ethnographically, the Old Russian source is not impossible. Budziszewska (1985: 119) mentions that mamuna (the creature) also appears in Polish folklore under the name małpa, literary Polish for 'monkey, ape'. The attestations are from south-eastern Mazovia, the Lublin Voivodeship, south-east of Lviv, and also from Ukrainian. But in itself, this piece of information does not in fact build a bridge between Old Russian and Polish; the chain ORuss. мамонь 'a kind of monkey' > eastern Pol. małpa '1. monkey, ape; 2. an evil spirit' > central Pol. mamuna 'an evil spirit' has but two links, and both are missing something: the semantics between Old Russian and eastern Polish, and the very word between eastern and central Polish. Nonetheless, see 3.2.6 regarding apes and their behaviour towards children, and for a possible parallel example.

Perhaps the only realistic way in which this idea can be rescued is to assume that мамонъ also meant 'an evil spirit', and that the word mamuna had also been used in eastern Poland at some point in time, between which and today it was replaced by its Polish counterpart małpa. Both are believable, but we are not aware of any piece of evidence to support either. We should also consider how ORuss. мамонб could have possibly spread to northern Carpathians and central-southern Poland, leaving apparently no trace in Belarusian or Ukrainian. It was mentioned in 3.1 that we may have to prepare to accept an etymology containing a slightly improbable leap, but this one effectively hinges on three such assumptions.

\subsubsection{Lat. mammones}

Budziszewska's (1985: 119f) other idea is to explain our word from mediaeval Latin mammones 'simians', later contaminated with mamić. She reports after Rostafiński (1900: 432f) that monkeys were widely known in mediaeval Europe, and Polish attestations are as old as the $15^{\text {th }}$ and $16^{\text {th }}$ centuries, among others for 'guenon' under the name morska kotka lit. 'sea cat', a calque of G Meerkatze id. We mentioned several times above that mamunas were often pictured as particularly hirsute, and Budziszewska (1985: 120) adds that in one of the accounts they were said to mew rather than to speak.

Indeed, monkeys were fairly well known in the Middle Ages and sometimes they were even kept as house pets (LMA s.v. Affe; Walker-Meikle 2012: 55f, and others). However, they were also very expensive animals, and probably more familiar to the wealthy than to those for whom folklore was part of everyday life. In fact, Rostafiński (1900: 433) mentions from his own memory that the first monkey was brought to Zakopane only around 1882 .

As for the word mammones, it is included in Du Cange et al. (1883-1887) based on a single source (Guillelmus de Baldenzel, Hodoporico, p. 112) but further attestations proved very difficult to find, be it in databases (DLD; LLT-A; LLT-B) or through a Google search. More readily found is the derivative mamonetus, established in European zoology since the $13^{\text {th }}$ century in the meaning 'cercopithecinae' (Gesner 1551: 968; Baptista Bernardus 1582: 52; Rohn 1764: 165; Thomas 1909: 558f; 
see also Ambrosinus, Aldrovandi 1645: 244; GTB; had s.v. Affe; Stadler 1920: 1413f; Hünemörder 2001: 35, etc.).

The semantic aspect is here effectively the same as with ORuss. мамонб in 3.2.4, which is to say quite acceptable (see also 3.2.6), but the overall situation is nonetheless different. Unlike ORuss. мамонб, Lat. mamonetus clearly belongs to the learned vocabulary; the best chance it might have had to penetrate into the beliefs of the common folk would be through the clergy. It may have been that some priest or monk knew the word, identified it with an image of evil spirit that had already existed in the folklore (see 2 above), simultaneously with the devil, and then used it in his sermon, but we do not feel that this can in itself account for the spread of mamuna in Polish dialects, and beyond, in Czech, Slovak, and Ukrainian (see 3.1).

\subsubsection{It. gatto mammone}

The following is not a rigorous etymological hypothesis; our understanding of It. gatto mammone is not sufficiently clear for this, and there is also the question of geography. We merely mention the creature because it bears some ethnographic and phonetic similarity to mamuna, which appears to have been overlooked so far.

Janson (1952: 173, 194) mentions that apes are sometimes shown in mediaeval and Renaissance art and told in literature to abduct children and place their own offspring in their stead. This information certainly reinforces the semantic side of proposals 3.2.4 (ORuss. мамонб) and 3.2.5 (Lat. mammonetus), but at the same time it introduces another creature, the Italian 'monkey-cat' known most commonly as gatto mammone, but also gatto maimone $\sim$ gatto maimono $\sim$ gaito maimono $\sim$ gatto mammono gatto mammune (de Ritis 1845: 111; Janson 1952: 194; Sciacca 2004: 103; Domínguez 2006: 15; Treccani 2016).

The word is attested since the $14^{\text {th }}$ century with two meanings: 'a species of monkey' (probably one of Cercopithecinae), and 'evil spirit' (Borghi Cedrini 1996: 41; Passavanti c. 1355: 331.15 [after OVI]; Perfetti 2000: 173; Poggibonsi c. 1345: 75.8 [after OVI]; Sapere.it). Its etymology is not established. At least two sources have been proposed: Gr. mamùni 'scarab' (perhaps less likely semantically), and Tksh. majmun 'monkey, ape' (Battisti, Alessio 1975; Cortelazzo, Marcato 1998); possibly Lat. mammonetus (3.2.5) should also be taken into consideration. But the eventual origin is of lesser importance for us here.

More relevant is the mythical creature. Unhelpfully, its image is not very consistent. It is often said to be used to scare children (e.g. Janson 1952: 194; Contu 2004; Sapere.it), but e.g. in I. Calvino's rendition ("Il gatto mammone") it is a definitely positive, fair and benevolent character. Perhaps this is just a case of Calvino exercising his artistic license and mellowing a story he felt would be too harsh for the modern reader; but in the end, it is only the good sister who is rewarded while the lazy sister is cruelly punished, so the dark element has not been entirely removed. As for gatto mammone's appearance, it seems that very little can be said about it. A feline image is sometimes mentioned, owing no doubt to gatto in the name, but we have not been able to establish more for certain. 
Certainly, a more thorough investigation of gatto mammone would be necessary to turn this loose idea into an etymology. Whatever its results, however, it will be still very difficult to connect it with Cz., Pol., Slk. and Ukr. mamuna because there appear to be absolutely no traces of it remaining along whichever path it might have travelled from Italy (see 3.1). It may be that the only way in which gatto mammone will be of help in establishing the origin of mamuna in the future will be by providing a parallel example of conflation of 'monkey' and 'evil spirit' - and, perhaps, remembering Janson's account above, with the abduction of children.

\subsubsection{Kipch. majmun}

The following idea we present with just a little more conviction than It. gatto mammone. It is certainly not perfect but it is perhaps more promising.

Turkic mythology knows several ape-like creatures, but one of them is more interesting for us here. It goes by the name bičen $\sim$ mičin $\sim$ pečan $\sim$ pičan $\sim$ picen $\sim$ picin, and it is a feminine evil spirit in the form of a hirsute ape who lives in abandoned hunting huts, abducts those who wander alone in the forest, especially children, and does harm to them; it is also known to take on a more appealing form in order to lure men. It is attested in Tatar folklore, in the area of Omsk, Tobol, and Tymen. Sometimes, it is equated with other creatures from Turkic mythology, arśuri and šürele, though to our eyes the similarity is less than striking (Beydili 2004 s.v. şurele; MNM and MS s.vv. арсури́, пице́н, and шурале́ (the latter two are identical in both); Valeev 1976: 325; Zaripova Çetin 2007: 8f.). ${ }^{43}$

The name originally sounded bičin and meant quite simply 'monkey; ape' (Clauson 1972: 295f; DTS; MK: 271, 311). It was later ousted by Ar./Pers. maimūn id., but it is not clear when exactly the change took place. Most likely after the Islamization, but this was a relatively long process. On the one hand, we know that at least some of the soldiers under Mongol command in the $13^{\text {th }}$ century adhered to the ancient system of beliefs, while on the other, we find the word majmun attested in $12^{\text {th }}-14^{\text {th }} \mathrm{C}$. Codex Cumanicus (the modern Tatar shape is majmyl; see 3.2.4). We also know that a considerable proportion of the Mongol army in Europe was made up of Turkic peoples, and that their route through Poland led through the southern part of the country, with an excursion to the north in the centre - largely where the word mamuna is attested today.

It is tempting to speculate that, in the mix of tribes, languages, religions, and beliefs that constituted the Mongol army in the $13^{\text {th }}$ century, the demon bičin 'monkey; ape' would also have been sometimes called majmun id., and that this complex of beast and its name would have been identified by the Polish populace with their own pre-existing creature, so similar in appearance and behaviour (see 2 above). However, we must also admit that there is very little evidence of close contact between Mongol soldiers and European, or at least Polish folk. In fact, it appears that it is only in

4 Also in the Mongolic mythology we find a demon by the name of mičin. It is, however, a personification of the Pleiades and clearly connected with Tat. bičen only etymologically but not ethnographically (MNM s.v. ми́чин.) 
the $14^{\text {th }}$ century and later, when Tatars arrived in the Polish-Lithuanian Commonwealth on more peaceful terms (see e.g. Tyszkiewicz 2008) that such a contamination would have been possible (incidentally, cf. ORuss. мамонб in 3.2.4.). But would the theoretical bičin majmun alternation still exist then, and should we not expect some traces of the belief to be found in Lithuanian folklore and, most importantly, in the mythology of Polish-Lithuanian Tatars (see 3.1)? These are rather serious arguments but, unlike the majority of the doubts that we raised against other proposals above, these may be hoped to be removed simply by a (considerably) more thorough investigation.

To sum up, none of the seven etymologies of Pol. mamuna is entirely satisfactory. All the proposed etymons show some degree of similarity to our word and its meaning but lack one or more crucial property and, in the majority of cases, are also unlikely for other reasons. Most, however, are sufficiently similar to allow the possibility of contamination - including even between themselves and not necessarily with our mamuna. ${ }^{54}$ The semantics in Polish dialects varies somewhat and it seems quite likely to us that a considerable part of this diversity can be explained through the influence of one or more of the admittedly easily confused words above and the ethnographic complexes they represent. The details, however, require further investigation.

\section{Summary and conclusions}

The word mamuna is present in Poland in two independent clusters; the northern one in Warmia and Masuria; and the central-southern one which is geographically connected with (much rarer) attestations from Czechia, Slovakia, and the Ukraine. Ethnographically, they appear to refer to at least three separate complexes. The northern mamuna is most probably a borrowing of the Biblical Mammon 'wealth', 'personification of greed', likely via German (3.2.2). The southern one is more complex. It combines the ancient belief in child-swapping creatures with an equally old image of riverbank nymphs who lure and kill people. The former is more pronounced in central, the latter in southern Poland. This conflation results surely from the progressive dwindling of folk mythology. Czech and Slovak attestations represent the next step on the same path, where once dangerous demons are essentially reduced to bogeymen; the Ukrainian (Lemko, Hutsul) маму́н etc., together with eastern Polish forms, constitute a separate branch, one probably closer to the central Polish group.

The origin of the word itself remains unclear. We are aware of five previous attempts at an etymology, four of which assume a borrowing. We add two new

See e.g. Janson (1952: 37) on the possible link between the Biblical Mammon and names for 'monkey' deriving from Ar./Pers. maimūn such as Sp. maimon, OFr. mainmonet, E monkey, etc. Likewise, cf. ORuss. мамонъ and Kipch. majmun in 3.2.4 and 3.2.7, respectively. 
ideas here, both involving a foreign ancestry. Contamination is also often raised as a distinct possibility.

Indeed, there is no shortage of easily confused beliefs and words. Demons abducting children, demons abducting children and placing their own in their stead, hairy and ape-like demons, demons inhabiting the woods, riverbank demons are anything but rare in European, and other mythologies: Tkc. almas, Tat. bičin, Slav. boginki, Russ. chuchunya, E and Celtic elves and fairies, Brus., Pol. małpa, G Roggenmuhme (also known under multiple other names, see 3.2.3), Scandinavian trolls, Sp. xana, and numerous others. Words sounding similar to mamuna, and possessing an element of semantic similarity, are also not in short supply: apart from the ones listed in 3.2.1-3.2.7 we can name e.g. Slav. mamьnь 'foolish, stupid' (ESJS); Bulg. ма̀мница 'witch, sorceress' (3.1); various diminutives of mama 'mother, mum', such as Bulg. ма́минка (Gerovъ 1899), Pol. maтипia, etc.; Lith. mamántas, Russ. мáмонm 'mammoth' (LKŽ; Stachowski 200o); the many European and Asian offshoots of Ar./Pers. majmun 'monkey; ape', such as OFr. mainmonet and monin, OSp. mona, OOcc. monina, maybe also E monkey (OED) and perhaps even mannequin; Tkc. majmun, Kzk., Tat. majmyl (3.2.7; SKzkP), etc., perhaps also Oir. momon 'mole cricket', nomon 'mole' (OirRS; Stachowski 2000: 306f).

But contaminations, because it seems likely that some may have occurred, do not quite suffice to explain the mamuna complex. Ethnographically, the core of the belief appears to belong to an ancient stratum, but it has not been preserved unchanged. Etymologically, the name mamuna is more likely than not to be a borrowing, but whether it is Oriental or not cannot as yet be said for certain.

\section{Abbreviations}

Ar. $=$ Arabic; Aram. $=$ Aramaic; Brus. $=$ Belarusian; Bulg. $=$ Bulgarian; Cz. $=$ Czech; dial. $=$ dialectal; E = English; Fr. = French; Gr. = Greek; G = German; It. = Italian; Kipch. = Kipchak; Kzk. = Kazakh; Lat. = Latin; Lith. = Lithuanian; O- = Old; Occ. = Occitan; Oir. = Oirot; Pers. $=$ Persian; Pol. $=$ Polish; Russ. $=$ Russian; Slav. $=$ Slavonic; Slk. $=$ Slovak; Sp. $=$ Spanish; Tat. $=$ Tatar; Tkc. $=$ Turkic; Tksh. $=$ Turkish; Ukr. $=$ Ukrainian

\section{References}

Ambrosinvs B., Aldrovandi V. 1645. Vlyssis Aldrovandi patricii Bononiensis de quadrvpedib.' digitatis viviparis libri tres et de qvadrvpedib' digitatis oviparis libri dvo. Bonon.

Anisov 1994 = Анисов Л.М. et al. 1994. Славянская мифология. Энциклопедический словарь. Москва.

Balsys R. 2014. Pagoniškojo lietuvių ir prūsų panteono raida. Klaipèda.

Bańkowski A. 2000. Etymologiczny słownik języka polskiego. [vol. 1]. Warszawa.

Baptista Bernardus I. 1582. Seminarij totius Philofophice. [vol. 2]. Venetia.

Bartoš F. 1885. Lid a národ. [vol. 2]. Velké Meziř́čí.

Battisti C., Alessio G. 1975. Dizionario etimologico italiano. [vol. 3]. Firenze.

$\mathrm{BBrz}=$ Biblia fwięta Tho jeft Kfiegi Stárego y Nowego Zakonu (...). 1563. Brześć Litewski. 
Beitl R. 2007. Untersuchungen zur Mythologie des Kindes. [ed. by B. Rieken, M. Simon; original work published 1933]. Münster, New York, München, Berlin.

Belova 2001 = Белова О.В. 2001. Славянский бестиарий. Москва.

BER = Георгиев В.И. et al. (eds.). 1979 [vol. 2], 1986 [vol. 3]. Български етимологичен речник. София.

Beydili C. 2004. Türk Mitolojisi Ansiklopedik Sözlük. Ankara.

BLeo = Biblia to ieft Kxięgi Stharego y Nowego Zakonu (...). 1561. [transl. by J. Nicz]. Kraków.

BNie = Biblia. To jeft kśięgi ftárego y nowego przymierza (...). 1572. [transl. by S. Budny]. Zasław or Uzda.

Borawski P., Dubiński A. 1986. Tatarzy Polscy. Dzieje, obrzędy, legendy, tradycje. Warszawa.

Borghi Cedrini L. 1996. Il nome «gatto lupesco». - Leonardi L. (ed.). Studi di filologia medievale offerti a d'Arco Silvio Avalle. Milano, Napoli: 27-45.

Bracha K. 2007. Nauczanie kaznodziejskie w Polsce późnego średniowiecza. Sermones dominicales et festivales $z$ tzw. kolekcji Piotra w Miłosławia. Kielce.

Brückner A. 1902. Literatura religijna w Polsce średniowiecznej. [vol. 1]. Warszawa.

Brückner A. 1989. Słownik etymologiczny języka polskiego. [original work published 1927]. Warszawa.

Budagovъ 1869 = Будаговъ Л. 1869. Сравнительный словарь туреияк-татарскихъ нартчій, со включеніемъ употребительнпйшихъ словъ арабскихъ и персидскихъ и съ переводомъ на русскій языкъ. [vol. 1]. Санктпетербургъ.

Budziszewska W. 1985. Z etymologii słowiańskich związanych z prastarymi wątkami folkloru. - Studia z filologii polskiej i słowiańskiej 23: 111-120.

BWuj = Biblia to iest księgi Starego y Nowego Testamentv (...). 1599. [transl. by I. Wvyek]. Kraków.

Calvino I. 1956. Fiabe italiane. Torino.

Černyh 2001 = Черных П.Я. 2001. Историко-этимологический словарь современного русского языка. [ $4^{\text {th }}$ edition, vol. 1]. Москва.

Clauson G. 1972. An etymological dictionary of pre-thirteenth-century Turkish. Oxford.

Contu G. 2004. Maimòne e mascara a gattu. (Note orientalistiche sulle maschere del carnevale di Sarule - Nuoro). [www.mamoiada.org/_pdf/_mamuthiss/maimone.pdf].

Cortelazzo M., Marcato C. 1998. I dialetti italiani. Dizionario etimologico. Torino.

DEX = Dicționar Român Explicativ Online. [www.dictionarroman.ro].

dexonline = Dicționare ale limbii române. [dexonline.ro].

DLD = Database of Latin Dictionaries. [www.brepolis.net].

Domínguez F.A. 2006. Monkey business in Carajicomedia: The parody of Fray Ambrosio Montesino as "Fray Bugeo". - eHumanista 7: 1-27.

Drimba V. 2000. Codex Comanicus. Edition diplomatique avec fac-similés. Bucarest.

DTS = Наделяев B.M. et al. (eds.). 1969. Древнетюркский словарь. Ленинград.

Du Cange C. et al. 1883-1887. Glossarium medice et infimoe latinitatis. Niort. [ducange.enc. sorbonne.fr].

Dźwigoł R. 2004. Polskie ludowe słownictwo mitologiczne. Kraków.

$\mathrm{EM}=$ Ranke K., Brednich R.W. et al. (eds.). 1975-2015. Enzyklopädie des Märchens. Handwörterbuch zur historischen und vergleichenden Erzählforschung. Berlin, New York.

ESJS = Etymologický slovník jazyka staroslověnského. 1996 [vol. 6], 1998 [vol. 8]. Praha.

ÈSSJa = Трубачёв О.Н. (еd.). 1983. Этимологический словарь славянских языков. Праславянский лексический фонд. [vol. 10]. Москва.

Fasmer 1967 = Фасмер М. 1967. Этимологический словарь русского языка. [vol. 2]. Москва. Filin 1975- = Филин Ф.П. et al. (eds.). 1975-. Словарь русского языка XI-XVII вв. Москва. 
Gebauer J. 1970. Slovník staročeský. [vol. 2]. Praha.

Georgieva 1993 = Георгиева И. 1993. Българска Народна Митология. [2 ${ }^{\text {nd }}$ edition]. София. Gerovъ 1899 = Геровъ Н. 1899. Рючникъ на блъгарскій языкъ. [vol. 3]. Пловдивъ.

Gesner C. 1551. Historice Animalium. [vol. 1]. Zürich.

Greń Z., Krasowska H. 2008. Słownik górali polskich na Bukowinie. Warszawa.

GTB = De Geïntegreerde Taalbank. [gtb.inl.nl; 24 ${ }^{\text {th }}$ March, 2016].

Gura 1997 = Гура А.В. 1997. Символика животных в славянской народной традиции.

Москва.

HdA = Hoffmann-Krayer E., Bächtold-Stäubli H. (eds.). 1987. Handwörterbuch zur deutschen Volkskunde. Abteilung I. Aberglaube. [original work published 1927-1942]. Berlin, New York. Hnatjuk 1912 = Гнатюк В. 1912. Знадоби до української демонольолії. [vol. 2.1]. Львів. HSSJ = Majtán M. (ed.). 1992. Historický slovník slovenského jazyka. [vol. 2]. Bratislava.

Hulubaș A. 2009. Inițierea. Definiri europene și tipare folclorice românești. - Botoșineanu L., Dănilă E., Holban C., Ichim O. (eds.). Distorsionări în comunicarea lingvistică, literară și etnofolclorică românească și contextul european. Iași: 597-613.

Hünemörder C. (ed.). 2001. Thomas de Cantimpré. Liber de natura rerum. [FarbmikroficheEdition der Handschrift Würzburg, Universitätsbibliothek, M. ch. f. 150]. München.

Janów J. 2001. Słownik huculski. Kraków.

Janson H.W. 1952. Apes and Ape Lore in the Middle Ages and the Renaissance. London. Jungmann J. 1836. Slownjk česko-německý. [vol. 2]. Praha.

Karłowicz J. 1903. Słownik gwar polskich. [vol. 3]. Kraków.

Kolberg 1962 = Krzyżanowski J., Burszta J. et al. (eds.). 1962. Oskar Kolberg. Dzieła wszystkie. [vol. 15: W. Ks. Poznańskie; original work published 1882]. Wrocław, Poznań.

Kolberg 1966 = Pawlak D., Ogrodziński W. (eds.). 1966. Oskar Kolberg. Dzieła wszystkie. [vol. 40: Mazury Pruskie]. Wrocław, Poznań.

Kott F.̌̌. 1890. Česko-německý slovník zvláště grammaticko-fraseologický. [vol. 6]. Praha.

Kryczyński S. 1938. Tatarzy litewscy. Próba monografii historyczno-etnograficznej. Warszawa. Kuun G. (ed.). 1880. Codex Cumanicus Bibliothece ad Templum Divi Marci Venetiarum. Budapestinum.

Leschber C. 2011. Lehnwege einiger Orientalismen und Wörter eurasischer Herkunft im Rumänischen und den sonstigen Balkansprachen. - Studia Etymologica Cracoviensia 16: 33-61.

Levkievskaja 2000 = Левкиевская Е. 2000. Мифы русского народа. Москва.

LKŽ = Lietuvių kalbos žodynas. 1941-2002. [www.lkz.lt].

LLT-A = Library of Latin Texts - Series A. [www.brepolis.net].

LLT-B = Library of Latin Texts - Series B. [www.brepolis.net].

LMA = Lexikon des Mittelalters. 1977-1980. [vol. 1]. München, Zürich.

Mannhardt W. 1868. Die Korndämonen. Beitrag zur germanischen Sittenkunde. Berlin.

Men 1680 = à Mesgnien Meninski F. 1680. Thesaurus linguarum orientalium turcica, arabicae, persicoe (...). Vienna.

Miklosich F. 1886. Etymologisches Wörterbuch der slavischen Sprachen. Wien.

MK = Dankoff R., Kelly J. (eds.). 1982. Maḥmūd al-Kāšyarī. Compendium of the Turkic dialects (Dīwān Luyāt at-Turk). [vol. 1]. Cambridge (MA).

MNM = Токарев С.A. et al. (eds.). 1988. Мифь народов мира. Энииклопедия. [2 $2^{\text {nd }}$ edition, vol. 2]. Москва.

MS = Мелетинский E.M. et al. (eds.). 1990. Мифологический словарь. Москва.

OED = Oxford English dictionary. [3 ${ }^{\text {rd }}$ edition, www.oed.com/view/Entry/113169].

OirRS = Баскаков Н.А., Тощакова Т.M. 1947. Ойротско-русский словарь. Москва.

OVI = Larson P., Artale E. (eds.). n.d. Corpus OVI dell'Italiano antico. [gattoweb.ovi.cnr.it]. 
Paškoŭ et al. 2005-2006 = Пашкоў Г.П. et al. 2005-2006. Беларускі фальклор. Энцыьклапедыя. Мінск.

Passavanti c. 1355 = Polidori F.L. (ed.). 1856. Lo Specchio della vera penitenza di Iacopo Passavanti. Firenze.

Pełka L.J. 1987. Polska demonologia ludowa. Warszawa.

Perfetti S. 2000. Aristotle's zoology and its Renaissance commentators (1521-1601). Leuven.

Plotnikova 2004 = Плотникова А.А. 2004. Мифологическая лексика сербско-болгарского пограничья. - Калнынь Л.Э. et al. (eds.). Исследоварния по славянской диалектологии. [vol. 10: Терминологическая лексика материальной и духовой культуры балканских славян]. Москва: 92-142.

Plotnikova 2009 = Плотникова А.А. 2009. Материалы для этнолингвистического изучения балканославянского ареала. Москва.

Poggibonsi c. 1345 = Bacchi Della Lega A. (ed.). 1881. Libro d'oltramare di Niccolò da Poggibonsi. Bologna.

Preobraženskij 1910 = Преображенский А. 1910. Этимологическій словарь русскаго языка. [vol. 1]. Москва.

PSJČ = Hujer O. et al. (eds.). 1937-1938. Příruční slovník jazyka českého. [vol. 2]. Praha.

$\mathrm{R}$ = Радлов В.В. 1911. Опытъ словаря тюркскихъ нарпчій. Versuch eines Wörterbuches der Türk-Dialecte. [vol. 4.2]. Санктъ-Петербургъ.

Ritis V. de. 1845. Vocabolario napoletano lessigrafico e storico. [vol. 1]. Napoli.

Rohn J.K. 1764. Nomenclator. To gest: Gmenowatel, Aneb Rozličných Gmen Gak w Cžejké, Latinfké, taky w Německé Ržeči (...). [vol. 1]. Praha.

Rostafiński J. 1900. Symbola ad historiam naturalem medii aevi. [vol. 1]. Cracovia.

$\mathrm{RP}=$ Rozmyślanie przemyskie. [www.ijp-pan.krakow.pl/images/publikacje_elektroniczne/ korpus_tekstow_staropolskich/Rozm.pdf].

Sanьko et al. 2004 = Санько С., Валодзіна Т., Васілевіч У. et al. 2004. Беларуская міфалогія. Энцыклапедычны слоўнік. Мінск.

Sapere.it $=[$ www.sapere.it/sapere/enciclopedia.html].

Sciacca G.C. 2004. Fonti per una storia di tindari e patti. Roma.

SGOWM = Stamirowska Z., Perzowa H. (eds.). 1987-. Słownik gwar Ostródzkiego, Warmii i Mazur. Ossolineum.

SGP = unpublished files for Karaś M., Reichan J., Okoniowa J. et al. (eds.). Słownik gwar polskich. [courtesy of the Institute of the Polish Language of the Polish Academy of Sciences in Kraków].

SKzkP = Aqtay G., Jankowski H. 2011. Słownik kazachsko-polski. Kraków.

Smatana M. 2004. Ktože to tu straší, čože to tu máta (1). - Kultúra slova 38.3: 158-168.

Sreznevskij 1902 = Срезневскій И.И. 1902. Матеріаль для словаря древне-русскаго языка по письменнымъ памятникамъ. [vol. 2]. Санктпетербургъ.

SSJ = Peciar Š. (ed.). 1960. Slovník slovenského jazyka. [vol. 2]. Bratislava.

Stachowski M. 2000. Das Wort Mammut in etymologischen Wörterbüchern. - Folia Orientalia 36: 301-314.

Stachowski M. 2005. Karpatyzm leksykalny. - Zeszyty Naukowe Uniwersytetu Jagiellońskiego. Prace Językoznawcze 122: 179-188.

Stachowski M. 2007. Das Ungarische unter den Karpatensprachen. - Studia Linguistica Universitatis Iagellonicae Cracoviensis 124: 119-125.

Stachowski M. 2012. Ein neues Wörterbuch der Türkischen Lehnwörter in Balkan- und Karpatensprachen und Ukrainisch bánuš 'Maisbrei'. - Studia Etymologica Cracoviensia 17: 191-197. 
Stadler H. (ed.). 1920. Albertus Magnus. De Animalibus Libri XXVI. Nach der Cölner Urschrift. [vol. 2]. Münster.

Šuchevyč 1899 = Шухевич В. 1899. Гуиульщина. [vol. 1]. Львів.

Sumców M. 1891. Boginki-mamuny. - Wisła 5.3: 572-587.

TatRS = Асылгараев Ш.Н., Ганиев Ф.А., Закиев М.З., Миннуллин К.М., Рамазанова Д.Б. (eds.). 2007. Татарско-русский словарь. Татарча-русча сүзлек. Казань.

Thomas A. 1909. Notes étymologiques et lexicographiques (suite). - Romania 38: 553-586.

Tolstoj 2003 = Толстой Н.И. 2003. Очерки славянского язычества. Москва.

Treccani $2016=$ [www.treccani.it; $3^{\text {rd }}$ April, 2016].

Tyszkiewicz J. 1989. Tatarzy na Litwie i w Polsce. Studia z dziejów XIII-XVIII w. Warszawa. Tyszkiewicz J. 2008. Tatarzy w Polsce i Europie. Fragmenty dziejów. Pułtusk.

UkrLit = Укрліт.org. Публічний електронний словник української мови. [ukrlit.org/ slovnyk].

Valeev 1976 = Валеев Ф.Т. 1976. О религиозных представлениях западносивирских татар. - Вдовин И.С. (еd.). Природа и человек в религиозных представлениях народов Сибири и Севера (вторая половина ХІХ - начало ХХ в.). Ленинград: 320-332.

Valencova 2013 = Валенцова М.М. 2013. Мифологический аспект словацкой фразеологии. - Гура А.В., Белова О.В., Березович Е.Л. (eds.). Slavica Svetlanica. Язык и картина мира. Кюбилею Светланы Михайловны Толстой. Москва: 194-202.

Verchatskyj 1902 = Верхатский I. 1902. Про говор галииких Лемків. Львов.

Vinogradova 2000 = Виноградова Л.Н. 2000. Народная демонология и мифо-ритуальная традиция славян. Москва.

Vinogradova 2004 = Виноградова Л.Н. 2004. Мамуна. - Толстой Н.И. (ed.). Славянские древности: этнолингвистический словарь. Москва: 176-178.

Vinogradova, Levkievskaja 2012 = Виноградова Л.Н., Левкиевская Е.Е. 2012. Народная демонология Полесья. Публикации текстов в записах 80-90-х годов ХХ века. Москва.

Walker-Meikle K. 2012. Medieval pets. Woodbridge.

Wörterbuchnetz $=$ [woerterbuchnetz.de].

Zaripova Çetin Ç. 2007. Tatar Türklerinde Mitolojik Varlıklarla İlgili Mitler Ve İnanışlar (İyeler ve Yaratıklar). - bilig 43: 1-32.

Zelenin 1995 = Зеленин Д.К. 1995. Избранные труды. Очерки русской мифологии: Умершие неетественною смертью и русалки. Москва.

Zíbrt Č. 1888. Směs. - Světozor 52 [16 ${ }^{\text {th }}$ November]: 832. 